\title{
SYMPLECTITES IN UPPER MANTLE HARZBURGITES AND GARNET HARZBURGITES
}

Field, S.W.

Stockton State College, Pomona New Jersey, 08240

Svmplectites are complex mineral interorowths commonly found in upper mantle peridotites recovered from kimberlite pipes (Exlev et.al., 1982; Dawson and Smith. 1975). Svmplectites are abundant in harzburgites and garnet harzburgites found in the Cretaceous Jagersfontein kimberlite in South Africa. svmplectites in harzburgites are composed of either enstatite, diopside, and spinel or diopside and spinel. Svmplectites in a arnet harzburgites are composed of either diopside, garnet, and spinel or garnet and spinel. Amphibole is found in a fen: svmplectites and is thought to be of metasomatic origin. Temperature estimates for the garnet harzburgites obtained from Lindsley and Andersons (1983) two pyroxene geothermometer range from 650 to $1300 \mathrm{c}$ with most falling between 850 and $1000 \mathrm{c}$. Pressure estimates from garnet-diopside geobarometry (Brey et.al., 1986) range from 12 to 47 kilobars with most estimates falling between 20 and 35 kilobars. Temperature estimates tor simplectite-bearing harzburgites range from a low of $775 \mathrm{c}$ to a high of $1300 \mathrm{c}$.

Petrography: Harzburgites containine symplectites are composed dominantly of medium-grained olivines $(0.5-2.0 \mathrm{~mm})$ surrounding cluster of enstatites. Symplectites. oenerallv less than $0.5 \mathrm{~mm}$ in dianeter, make up less than 1 modal percent of the peridotites. Svmplectites are constructed of a single or smal 1 number of optically homogeneous pyroxene crystals embedded with tens to hundreds of small, wavy, spinel lamellae. 'The svmplectites are located adiacent to discrete enstatite and are senerallv triangular or arcuate in shape. Spinel lamellae are crvstallographically oriented in the pyroxene and radiate outward away from the enstatite.

Garnet harzburgites are composed of clusters of large discrete enstatites surrounded by olivines. Within the enstatite clusters are small interstitial garnets, spinels, and diopsides. Enstatites contain abundant planar lamellae of spinel, diopside and in some samples garnet. svmplectites are located within enstatite clusters adiacent to lamellae-bearing pyroxenes. Symplectite structure consists of either small spinel blebs within large garnets or commontv a central core of diopside crystals embedded with tens to hundreds of wary spinel lanellae surrounded by a rim or partial rim of garnet.

Mineral Chemistry: Olivines in harzburgites and garnet harzburgites have identical chemistries and range trom fogz to Fog4. Diopsides in harzburoites, present dominant 1 y in symplectites, have a lower $\mathrm{Na}$ content $1.02-.08 \mathrm{cat} .16$ oxyl and slightly higher Mg content (.93-.96 cat./6 oxv) than diopsides in 
garnet harzburgites ( $\mathrm{Na} .03-.13, \mathrm{Mg} .90-.96$ cat./6 oxy). l)iscrete enstatite in harzburgites differ compositionally from enstatites in garnet harzburgites. Harzburgite enstatite Al contents $(.03-.14$ cat./6 oxy). Ca contents $(.01 .04$ cat./6 oxy) and $\mathrm{Cr}$ contents are higher than A $1.03-.05$ cat./6 ox. $), \mathrm{Ca}(<.01$ cat. $/ 6$ oxvl, and Cr contents in oarnet harzburgite enstatites. silicon and magnesium contents in harzburgite enstatites are distinctlv lower than $\mathrm{Si}$ and $\mathrm{Ma}$ contents in sarnet harzburgite enstatites. In addition discrete harzburgite enstatites are enriched in $\mathrm{Ca}, \mathrm{Al}$, and $\mathrm{Cr}$ contents with respect to enstatites in svmplectites (Al.04-.09, Ca .01-.02 cat./6 oxy). Svmplectite enstatites in harzburgites are intermediate in chemistry to discrete harzburgite enstatites and discrete garnet harzburgite enstatites.

Svmplectite spinels in harzburgites are Mg $15.3-6.1$ cat./32 oxv) and Al rich $(6.8-11.2$ cat. $/ 32$ oxv $)$ and $\mathrm{Cr}(4.8-8.5 \mathrm{cat} . / 32$ oxy) and Fer poor $(2.0-2.8 \mathrm{cat} .132$ oxy $)$. Spinels in garnet harzburgites are found as lamellae in enstatite, as small discrete interstitial grains, and as lamellae in svmplectites. All the garnet harzburgite spinels are $\mathrm{rich}$ in Fe $(3.2-4.4$ cat. $/ 32 \mathrm{oxv})$ and $\mathrm{Cr}(9.7-10.9 \mathrm{cat} . / 32 \mathrm{oxy})$ and poor in $\mathrm{Mg}$ (4.65.2 cat. $/ 32$ oxv) and Al (4.1-6.2 cat./32 oxy). Although spinels in harzburgites and sarnet harzburgites have generally difterent compositons the compositions form a continuous trend from Mo and Al rich to $\mathrm{Fe}$ and $\mathrm{Cr}$ poor. Garnets found only in garnet harzburgites, are found as lamellae in enstatites, discrete interstial grains, and as rims or partial rims around svmplectites. Garnets have a 1 imited range in composition (Py 67-73 Alm 12-19 Sp $0.5-1.5$ ' in all morphological forms.

Discussion: The petrography and chemistry of minerals in svmplectites and svmplectite-bearing peridotites indicate that intergrowth formation was complex and involved exsolution. diffusion, metamorphism, and in some cases metasomatism and that s.vmplectites in harzburgites and sarnet harzbursites mav be genetically related. Lamellae in enstatite and the position of symplectites adiacent to lamellae-bearing enstatites indicates symplectite diopside diffussed out of enstatite. The optical. orientation of spinel in symplectites and the textural relationship of spinel to pyroxene suggest that spinel unmixed from diopside after the pyroxene diffused from enstatite. Garnet appears to have formed by a reaction between olivine or enstatite, spinel, and diopside after formation of the svmplectite core. Metasomatic reactions formed amphibole by replacement of garnet, diopside, enstatite, and spinel in some peridotites. Harzburgites which contain high Al discrete enstatites and modally minor symplectites mav be precursors to garnet harzburgites containing low Al enstatites and a modallv higher percentage of spinel, diopside, and garnet. 
Table 1. Mineral Chemistrv

$\begin{array}{lcccccccc} & 1 & 2 & 3 & 4 & 5 & 6 & 7 & 8 \\ \mathrm{Si} & .996 & 2.992 & 1.977 & 1.926 & 1.935 & 1.993 & 0 & 0 \\ \mathrm{Ti} & 0 & 0 & .001 & .001 & 0 & 0 & 0 & 0 \\ \mathrm{Al} & 0 & 1.856 & .076 & .138 & .097 & .029 & 8.158 & 4.708 \\ \mathrm{Cr} & 0 & .170 & .030 & .020 & .021 & .005 & 7.548 & 10.575 \\ \mathrm{Fe}+ & 0 & - & - & - & - & - & .294 & .717 \\ \mathrm{Fe}+ & .139 & .490 & .044 & .129 & .129 & .139 & 2.404 & 2.817 \\ \mathrm{Mn} & 0 & .029 & - & 0 & 0 & .004 & .045 & .051 \\ \mathrm{Ma} & 1.860 & 2.080 & .946 & 1.736 & 1.810 & 1.820 & 5.552 & 5.133 \\ \mathrm{Ca} & 0 & .389 & .881 & .027 & .024 & .006 & - & - \\ \mathrm{Na} & .006 & - & .035 & & .001 & 0 & .002 & -\end{array}$

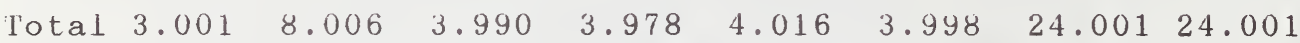

1. Olivine - cat./4 oxr

2. Garnet - cat./12 oxv

3. Diopside cat./6 oxv

4. Enstatite (Discrete, Harzburgite) cat./6 oxv

5. Enstatite (svmplectite. Harzburoite) cat./b oxv.

6. Enstatite (Discrete, Garnet Harzburgite) cat./6 oxy.

7. Spinel (Srmplectite, Harzburgite) cat./32 oxy.

8. Spinel (Svmplectite, Garnet Harzburgite) cat./32 oxy.

Brey, G.P., Nickel, K.G., Kogarko, L., 1986, Garnet-pyroxene equilibria in the system CaO-MgO-AL2O3-SiO2 (CMAS): prospects for simiplified ( T.independent) Iherzolite barometry and an ecologite barometer. Contrib. Mineral. Petrol., v 92, p. 448455 .

Dawson, J.B.. Smith, J.V., 1975, Chromite-silicate intergrowths in upper-mant]e peridotites: In L.H. Ahrens, J.B. Dawson, A.K., Duncan. A.J. Erlank, Eds.. Physics and Chemistry of the Earth, v.9, p. 339-350, Pergamon Press. New York.

Exlev, R.A., Smith, J.V., Hervig. R.L., 1982, Cr-rich spinel and garnet in two peridotite xenoliths from the Frank Smith mine South Africa: Significance of Al and Cr distribution between spinel and sarnet. Min. Mag., Vol 45, p. 129-134.

Lindsley, D.H.. Anderson, D.J., 1983, A two-pyroxene thermometer: Proceedings of the thirteenth Lunar and Planetary Science Conference. Journal of Geophysical Kesearch, Vol. 88, p. A 887 - A906. 